\title{
Morbidity in neonates according to the mode of delivery: a comparative study
}

\author{
Morbidade em recém-nascidos de acordo com a via de parto: um estudo comparativo
}

\author{
Maria Cecilia Santa Cruz Breim¹, Conceição Aparecida de Mattos Segre², Umberto Gazi Lippi ${ }^{3}$
}

\begin{abstract}
Objective: The objective of this study was to compare the effects of the modes of delivery on the health of newborns in a private maternity hospital in the city of São Paulo. Methods: Between January 1995 and December 1998, all patients consecutively admitted for deliveries were included in this cross-sectional retrospective study. A total of 8,457 medical records were analyzed, being excluded of the sample 460 multiple pregnancies and 517 pregnant women with obstetric and/or clinical disorders. The incidence of neonatal birth injury, respiratory distress and anoxia was analyzed, as well as birth weight, type of delivery and gestational age (according to Näegele and Capurro). Results: The final sample consisted of 7,480 neonates, and $69.6 \%$ were born by cesarean section, $24 \%$ vaginally and $6.4 \%$ through the vagina with the aid of forceps. A significant association was found between anoxia and the three types of delivery $(p<0.001)$. Respiratory distress was more frequent in cesarean delivery in newborns with gestational age superior to 37 weeks and in newborns weighing more than or equal to $2,500 \mathrm{~g}$. Respiratory distress was significantly associated with cesarean delivery and/ or forceps delivery, as compared with vaginal delivery, in the entire sample. Neonatal birth injury was associated with the use of forceps. In neonates born by cesarean section, anoxia was associated with lower gestational age estimated by the Capurro method and with lower weight. Conclusions: The abdominal approach is associated with greater morbidity of fetuses due to respiratory distress. Vaginal delivery is safer in newborns with more than 37 weeks of gestation and in those weighing more than $2,500 \mathrm{~g}$.
\end{abstract}

Keywords: Natural childbirth; Cesarean section; Obstetrical forceps; Morbidity; Obstetric labor complications; Comparative study

\section{RESUMO}

Objetivo: Analisar comparativamente os efeitos dos tipos de parto sobre a saúde do recém-nascido em maternidade privada da cidade de São Paulo. Métodos: Entre janeiro de 1995 e dezembro de 1998, incluíram-se no estudo transversal retrospectivo todas as pacientes consecutivamente internadas para dar à luz. Foram analisados 8.457 prontuários, excluídas 460 gestações múltiplas e 517 gestantes com afecções obstétricas e/ou clínicas. Foram analisadas as incidências de tocotraumatismo, desconforto respiratório e anoxia, avaliando-se o peso ao nascer, o tipo de parto e a idade gestacional (conforme Näegele e Capurro). Resultados: A amostra final constituiu-se de 7.480 recém-nascidos, sendo que $69,6 \%$ nasceram por cesárea, $24 \%$ por parto normal e $6,4 \%$ com auxílio de fórcipe. Houve associação significativa entre anoxia e os três tipos de parto $(p<0,001)$. 0 desconforto respiratório foi mais frequente no parto tipo cesárea em recém-nascidos com mais de 37 semanas de idade gestacional e em recém-nascidos com peso maior ou igual a $2.500 \mathrm{~g}$. Essa complicação teve associação significativa com parto cesariano e/ou fórcipe, mas não com parto normal na amostra total. 0 tocotraumatismo associou-se ao uso do fórcipe. Em recém-nascidos por cesárea, a anoxia associouse à menor idade gestacional estimada pelo método de Capurro e ao menor peso. Conclusões: A via abdominal incorre em maior morbidade para 0 feto em termos de desconforto respiratório. 0 parto vaginal mostrou-se mais seguro para recém-nascidos com idade gestacional superior a 37 semanas e em recém-nascidos com peso maior que $2.500 \mathrm{~g}$.

Descritores: Parto normal; Cesárea; Forceps obstétrico; Morbidade; Complicações do trabalho de parto; Estudo comparativo

\section{INTRODUCTION}

Despite the recommendations in the literature, Brazil has not accomplished the ideal rate set by the World Health Organization (WHO) for cesarean delivery ${ }^{(1)}$. A Brazilian study showed a $72 \%$ rate at private hospitals and $31 \%$ at public hospitals ${ }^{(2)}$. According to the WHO, $15 \%$ of deliveries have precise indication for cesarean section (C-section), that is, there are instances in which

\footnotetext{
Study carried out at Hospital Israelita Albert Einstein - HIAE, São Paulo (SP), Brazil.

${ }^{1} \mathrm{MD}, \mathrm{MsC}$ at Hospital Israelita Albert Einstein - HIAE; postgraduate student (Master degree) do Instituto de Assistência Médica ao Servidor Público Estadual - IAMSPE, São Paulo (SP), Brazil.

${ }^{2}$ Post-doctorate degree in Neonatal Pediatrics; Lecturer of the Perinatology Course of Instituto Israelita de Ensino e Pesquisa Albert Einstein - IEPAE, São Paulo (SP), Brazil.

${ }^{3} \mathrm{PhD}$; MD at Hospital do Servidor Público Estadual "Francisco Morato de Oliveira" - HSPE-FMO, São Paulo (SP), Brazil.

Corresponding author: Maria Cecilia Santa Cruz Breim - Avenida Portugal, 220 - Brooklin - CEP 04559-000 - São Paulo (SP), Brazil - Tel.: (11) 5543-8214 - e-mail: ceciliabreim@gmail.com

Received on Mar 5, 2010 - Accepted on Jun 9, 2010
} 
it is mandatory for the preservation of maternal and/or fetal health ${ }^{(2)}$.

Some authors stated that the acceptable rate of cesarean deliveries for tertiary-care maternity should be between 10 and $12 \%$ for single gestations, with the exception of an interventionist attitude in the case of very low birth weight newborns ${ }^{(3)}$. In a review article on C-section published in 2003, it is stated that the acceptable rates range from 15 to $30 \%$ for low- and medium-risk gestations, and $40 \%$ for high obstetric and/or perinatal risk pregnancies ${ }^{(4)}$.

The incidence of cesarean deliveries in Brazilian hospitals is high and it is intriguing that this value is higher at private institutions. A $72 \%$ rate of cesarean deliveries was found in private hospitals and $31 \%$ in public hospitals studied in Brazil(2). According to DATASUS, the proportion of cesarean sections paid by the SUS (Brazilian public health system) in 2003 was $26.39 \%$ of deliveries. In the same period, the average proportion of cesarean deliveries in private institutions was $81.69 \%$, according to data sent to the SIP (Information System of ANS Products - Ministry of Health) by health insurance plans ${ }^{(2)}$.

In Brazil, health insurance plans are regulated by the National Supplementary Care Agency (ANS) (in Portuguese, Agência Nacional de Saúde Suplementar), which adopts the proportion of cesarean deliveries per hospital or maternity as one of the quality indicators of delivery care. This proportion is the ratio of the total number of $\mathrm{C}$-sections and the total number of deliveries - vaginal plus C-sections - performed at one site in a given period ${ }^{(2)}$. According to the ANS, this indicator enables assessing the quality of care provided, because an increase in this ratio may reflect inadequate prenatal care or mistaken indications for surgical rather than vaginal delivery ${ }^{(2)}$.

A systematic literature review recently published showed that cesarean delivery with no labor, at gestational age lower than 40 weeks, is less recommended because of its association with increased risk of respiratory morbidity for the newborn (NB). Therefore, children born by $\mathrm{C}$-section at 37 weeks have five-fold more chance of severe respiratory disease than term delivered newborns; at 38 weeks, the chance is fourfold higher and twice higher at 39 weeks. However, the risk at 39 weeks was not statistically significant ${ }^{(5)}$.

These observations raised questions regarding the quality of delivery by hospitals, especially the private ones. In an ANS registry, the rate of cesarean deliveries reported by health insurance plans was $81.69 \%$ in 2003, while that performed at SUS (Brazilian public health system) was of $26.39 \%$ in the same year when comparing the clinical outcome of newborns delivered vaginally to those by $\mathrm{C}$-section, the morbidity associated with either mode of delivery becomes evident. Therefore, studies comparing the outcome of babies born by $\mathrm{C}$-section and vaginal delivery are pertinent in order to gather useful data for establishing recommendations for the best care of the mother and her offspring.

\section{OBJECTIVE}

The objective of the present study was to comparatively analyze the effects of abdominal route and vaginal route deliveries on the newborn in a large private maternity in the city of São Paulo.

\section{METHODS}

\section{Design, site, participants and study size}

The present study has a cross-sectional retrospective design, including consecutively admitted patients for giving birth at Hospital Israelita Albert Einstein (HIAE), between January 1995 and December 1998.

HIAE is a private hospital that serves well off patients who have good healthcare plans or pay for their inpatient stay. Other studies showed that the total number of pregnant women seen at this hospital received prenatal care, $94.6 \%$ having six visits or more, $61.1 \%$ had college degree, $97.9 \%$ had health insurance, and their mean age was 31.1 years and $0.9 \%$ were teenagers ${ }^{(6)}$.

The medical charts of 8,457 pregnant women admitted to the HIAE were analyzed, whether or not they were in labor and at any gestational age. Four hundred and sixty multiple gestations and 517 pregnant women with obstetric (such as preeclampsia and others) and/or clinical disorders (pre-existing hypertension and cardiopathy, among others) were excluded.

After the exclusion, the sample included 7,480 patients.

\section{Data collection and variables}

Data was obtained from perinatal medical charts completed by pediatricians caring for the newborns at the delivery room and during their hospital stay. These data is in the digitalized database organized for this type of study. Data collection was approved by the Research Ethics Committee of the HIAE.

The studied variables included:

- incidence of anoxia according to definition of the assisting neonatologist and recorded in the charts;

- incidence of respiratory distress;

The following diagnoses were considered to be respiratory distress: transient tachypnea, hyaline membrane, pulmonaryhypertension, bronchopneumonia, 
adaptive respiratory distress, pneumomediastinum, pneumonia, congenital pneumonia, pneumothorax.

- incidence of neonatal birth injury;

Each of these variables was evaluated in regard to:

- mode of delivery (vaginal or abdominal), intercurrences and use of maneuvers and procedures with the use of forceps;

- gestational age calculated according to the Näegele rule;

- estimated gestational age after birth according to the Capurro method;

- birth weight in grams.

\section{Statistical analysis}

To study the association between two qualitative variables, $\chi^{2}$ was used. The quantitative variables - birth weight, gestational age and gestational age estimated by the Capurro method - do not have a normal distribution; therefore, the comparison between the two groups (with or without disorders) was carried out using the nonparametric Mann-Whitney test, represented by the $\mathrm{Z}$ value. Significance was considered with $p$ values lower than $5 \%$.

The Statistical Package for the Social Sciences (SPSS), version 11.5, was used for data analysis.

\section{RESULTS}

\section{General newborn sample}

The total sample was composed of 7,480 newborns in the study period at HIAE, out of which 5,205 (69.6\%) were born by C-section, $477(6.4 \%)$ vaginally with forceps and 1,798 (24\%) by vaginal delivery.

\section{Anoxia}

Anoxia occurred in $388 \mathrm{NB}$ ( $5.2 \%$ of the sample). Out of these, 240 were born by C-section $(3.2 \%$ of total NB with anoxia), $58(0.8 \%)$ by forceps and $90(1.2 \%)$ by vaginal delivery. The $\chi^{2}$ test showed that there was a statistically significant association between the mode of delivery and anoxia $\left(\chi^{2}=50.78\right.$; $\left.p<0.001\right)$. When compared two by two, there was no difference between vaginal and cesarean deliveries regarding the occurrence of anoxia, but there was a significant association with forceps delivery, when compared with both normal $\left(\chi^{2}=31.72 ; \mathrm{p}<0.001\right)$ and Cesarean deliveries $\left(\chi^{2}=50.10 ; \mathrm{p}<0.001\right)$ (Table1).

A total of 394 (5.3\% of total deliveries) neonates were less than 37 weeks of gestational age and anoxia occurred in $39 \mathrm{NB}$ of this group, corresponding to $10 \%$ of the preterm children. It also occurred in $27(6.9 \%)$ babies born by C-section, in $5(1.3 \%)$ of those born by forceps application, and in $7(1.8 \%)$ of those born by vaginal delivery. There was no statistical significance for such condition when the three types of delivery were compared at this gestational age $\left(\chi^{2}=2.73 ; \mathrm{p}=0.256\right)$ (Table 2).

In the group of the 7,086 NB at gestational age equal to or greater than 37 weeks, anoxia occurred in $349(4.9 \%)$ babies, $213(3 \%)$ of them born by C-section, $53(0.7 \%)$ by forceps and $83(1.2 \%)$ by vaginal delivery. There was a statistically significant association among the modes of delivery $\left(\chi^{2}=48.59 ; \mathrm{p}<0.001\right)$ (Table 3 ), with the highest incidence for forceps delivery.

Among NB with weight between 1,500 and 2,499 g (317), there were 29 with anoxia, corresponding to $9.1 \%$ in this weight group. Twenty-four (7.6\%) of them were born by C-section, $3(0.9 \%)$ by forceps delivery and $2(0.6 \%)$ by vaginal delivery. There was a statistically significant association among the three modes of

Table 1. Frequency of complications per mode of delivery in the total sample

\begin{tabular}{|c|c|c|c|c|c|c|c|c|c|}
\hline \multirow{2}{*}{$\begin{array}{l}\text { Mode of } \\
\text { delivery }\end{array}$} & \multicolumn{3}{|c|}{$\begin{array}{c}\text { Anoxia } \\
\chi^{2}=50.78 ; p<0.001\end{array}$} & \multicolumn{3}{|c|}{$\begin{array}{c}\text { Respiratory distress } \\
\chi^{2}=11.20 ; p=0.004\end{array}$} & \multicolumn{3}{|c|}{$\begin{array}{c}\text { Birth injury } \\
\chi^{2}=329.05 ; p<0.001\end{array}$} \\
\hline & $\begin{array}{c}\text { No } \\
\text { n (\%) }\end{array}$ & $\begin{array}{c}\text { Yes } \\
\mathrm{n}(\%)\end{array}$ & $\begin{array}{l}\text { Total } \\
\text { n (\%) }\end{array}$ & $\begin{array}{c}\text { No } \\
\mathrm{n}(\%)\end{array}$ & $\begin{array}{c}\text { Yes } \\
\mathrm{n}(\%)\end{array}$ & $\begin{array}{l}\text { Total } \\
\text { n (\%) }\end{array}$ & $\begin{array}{c}\text { No } \\
\text { n (\%) }\end{array}$ & $\begin{array}{c}\text { Yes } \\
\text { n (\%) }\end{array}$ & $\begin{array}{l}\text { Total } \\
\text { n (\%) }\end{array}$ \\
\hline Forceps & $419(5.6)$ & $58(0.8)$ & 477 (6.4) & $457(6.1)$ & $20(0.3)$ & $477(6.4)$ & 344 (4.6) & $133(1.8)$ & 477 (6.4) \\
\hline Vaginal & $1,708(22.8)$ & $90(1.2)$ & $1,798(24.0)$ & $1,758(23.5)$ & $40(0.5)$ & $1,798(24)$ & $1,689(22.6)$ & $109(1.4)$ & $1,798(24.0)$ \\
\hline
\end{tabular}

Table 2. Incidence of complications among newborns with less than 37 weeks of gestation

\begin{tabular}{|c|c|c|c|c|c|c|c|c|c|}
\hline \multirow{2}{*}{$\begin{array}{l}\text { Mode of } \\
\text { delivery }\end{array}$} & \multicolumn{3}{|c|}{$\begin{array}{c}\text { Anoxia } \\
\chi^{2}=2.73 ; p=0.256\end{array}$} & \multicolumn{3}{|c|}{$\begin{array}{c}\text { Respiratory distress } \\
\chi^{2}=0.33 ; p=0.846\end{array}$} & \multicolumn{3}{|c|}{$\begin{array}{c}\text { Birth injury } \\
\chi^{2}=18.29 ; \mathrm{p}<0.001\end{array}$} \\
\hline & $\begin{array}{c}\text { No } \\
\text { n (\%) }\end{array}$ & $\begin{array}{c}\text { Yes } \\
\mathrm{n}(\%)\end{array}$ & $\begin{array}{l}\text { Total } \\
\text { n (\%) }\end{array}$ & $\begin{array}{c}\text { No } \\
\text { n (\%) }\end{array}$ & $\begin{array}{c}\text { Yes } \\
\mathrm{n}(\%)\end{array}$ & $\begin{array}{l}\text { Total } \\
\text { n (\%) }\end{array}$ & $\begin{array}{c}\text { No } \\
\text { n (\%) }\end{array}$ & $\begin{array}{c}\text { Yes } \\
n(\%) \\
\end{array}$ & $\begin{array}{l}\text { Total } \\
\text { n (\%) } \\
\end{array}$ \\
\hline Forceps & $21(5.3)$ & $5(1.3)$ & $26(6.6)$ & 19 (4.8) & $7(1.8)$ & $26(6.6)$ & $18(4.6)$ & $8(2.0)$ & $26(6.6)$ \\
\hline Vaginal & $71(18.0)$ & $7(1.8)$ & 78 (19.8) & 60 (15.2) & $18(4.6)$ & 78 (19.8) & 72 (18.3) & $6(1.5)$ & 78 (19.8) \\
\hline
\end{tabular}


delivery and anoxia $\left(\chi^{2}=8.76 ; p=0.013\right)$ (Table 4$)$, the highest incidence of those by forceps delivery.

There were 7,163 NB with weight equal to or greater than 2,500 $\mathrm{g}$ and, among these, $359(5 \%)$ had anoxia. Out of these, $216(3 \%)$ were born by C-section, $55(0.8 \%)$ by forceps and $88(1.2 \%)$ by vaginal delivery. There was a statistically significant association between anoxia and the three types of delivery $\left(\chi^{2}=49.12 ; \mathrm{p}<0.001\right)$ (Table 5 ), with the highest incidence for those born by forceps.

\section{Respiratory distress}

Respiratory distress occurred in 260 NB (3.5\% of total). Of these, 200 (2.7\%) were born by C-section, $20(0.3 \%)$ by forceps delivery and $40(0.5 \%)$ by vaginal delivery. The $\chi^{2}$ test revealed a statistically significant association between respiratory distress and C-section and/or forceps delivery when compared with vaginal delivery $\left(\chi^{2}=10.57 ; \mathrm{p}=0.001\right.$ for vaginal/C-section and $\chi^{2}=5.69 ; \mathrm{p}=0.017$ for vaginal/forceps) (Table 1 ).

Respiratory distress occurred in 89 NB with less than 37 weeks of gestational age, that is, $22.6 \%$ of the group. It occurred in $64(16.2 \%)$ of those born by C-section, seven $(1.8 \%)$ of those born by forceps delivery and 18 $(4.6 \%)$ of those born by vaginal delivery. There was no statistically significant association between the mode of delivery and respiratory distress in this gestational age group $\left(\chi^{2}=0.33 ; \mathrm{p}=0.846\right)$ (Table 2$)$.

One hundred and seventy-one (2.4\%) NB with respiratory distress had gestational age equal to or greater than 37 weeks, of which $136(1.9 \%)$ were born by C-section, $13(0.2 \%)$ by forceps delivery and 22 $(0.3 \%)$ by vaginal delivery. There was a statistically significant association between respiratory distress and the three types of delivery $\left(\chi^{2}=12.43 ; p=0.002\right)$ for this gestational age group, vaginal delivery having the lowest incidence of the problem (Table 3 ).

Respiratory distress was found in $56 \mathrm{NB}$ weighing between 1,500 and 2,499 $\mathrm{g}(17.7 \%)$, among which 44 $(13.9 \%)$ were born by C-section, one $(0.3 \%)$ by forceps delivery and $11(3.5 \%)$ by vaginal delivery. There was no statistically significant association between the mode of delivery and respiratory distress for this birth weight group $\left(\chi^{2}=0.30 ; p=0.859\right)$ (Table 4$)$.

In the group of $\mathrm{NB}$ with weight equal to or greater than 2,500 g, respiratory distress occurred in $204(2.8 \%)$ cases. One hundred and fifty-six of them $(2.2 \%)$ were born by C-section, $19(0.2 \%)$ by forceps delivery and $29(0.4 \%)$ by vaginal delivery. There was a statistically significant association among the three types of delivery and respiratory distress $\left(\chi^{2}=12.85 ; \mathrm{p}=0.002\right)$, less incident among those born by vaginal delivery (Table 5).

Table 3. Incidence of complications among newborns with 37 or more weeks of gestation

\begin{tabular}{|c|c|c|c|c|c|c|c|c|c|}
\hline \multirow{2}{*}{$\begin{array}{l}\text { Mode of } \\
\text { delivery }\end{array}$} & \multicolumn{3}{|c|}{$\begin{array}{c}\text { Anoxia } \\
\chi^{2}=48.59 ; \mathrm{p}<0.001\end{array}$} & \multicolumn{3}{|c|}{$\begin{array}{c}\text { Respiratory distress } \\
\chi^{2}=12.43 ; \mathrm{p}=0.002\end{array}$} & \multicolumn{3}{|c|}{$\begin{array}{c}\text { Birth injury } \\
\chi^{2}=31.77 ; \mathrm{p}<0.001\end{array}$} \\
\hline & $\begin{array}{l}\text { No } \\
\text { n (\%) }\end{array}$ & $\begin{array}{c}\text { Yes } \\
\text { n (\%) }\end{array}$ & $\begin{array}{l}\text { Total } \\
\text { n (\%) }\end{array}$ & $\begin{array}{c}\text { No } \\
\text { n (\%) }\end{array}$ & $\begin{array}{l}\text { Yes } \\
\text { n (\%) }\end{array}$ & $\begin{array}{l}\text { Total } \\
\text { n (\%) }\end{array}$ & $\begin{array}{l}\text { No } \\
\text { n (\%) }\end{array}$ & $\begin{array}{c}\text { Yes } \\
\text { n (\%) }\end{array}$ & $\begin{array}{l}\text { Total } \\
\text { n (\%) }\end{array}$ \\
\hline Forceps & 398 (5.6) & $53(0.7)$ & 451 (6.3) & 438 (6.2) & $13(0.2)$ & 451 (6.4) & 326 (4.6) & $125(1.8)$ & 451 (6.4) \\
\hline Vaginal & $1,637(23.1)$ & $83(1.2)$ & $1,720(24.3)$ & $1,698(24.0)$ & $22(0.3)$ & $1,720(24.3)$ & $1,617(22.8)$ & $103(1.4)$ & $1,720(24.2)$ \\
\hline
\end{tabular}

Table 4. Occurrence of complications among newborns with weight between 1,500 and 2,499 g

\begin{tabular}{|c|c|c|c|c|c|c|c|c|c|}
\hline \multirow{2}{*}{$\begin{array}{l}\text { Mode of } \\
\text { delivery }\end{array}$} & \multicolumn{3}{|c|}{$\begin{array}{c}\text { Anoxia } \\
\chi^{2}=8.76 ; p=0.013\end{array}$} & \multicolumn{3}{|c|}{$\begin{array}{l}\text { Respiratory distress } \\
\chi^{2}=0.30 ; p=0.859\end{array}$} & \multicolumn{3}{|c|}{$\begin{array}{c}\text { Birth injury } \\
\chi^{2}=1.29 ; p=0.524\end{array}$} \\
\hline & $\begin{array}{c}\text { No } \\
\text { n (\%) }\end{array}$ & $\begin{array}{c}\text { Yes } \\
\text { n (\%) }\end{array}$ & $\begin{array}{l}\text { Total } \\
\text { n (\%) }\end{array}$ & $\begin{array}{c}\text { No } \\
\text { n (\%) }\end{array}$ & $\begin{array}{c}\text { Yes } \\
\text { n (\%) }\end{array}$ & $\begin{array}{l}\text { Total } \\
\text { n (\%) }\end{array}$ & $\begin{array}{c}\text { No } \\
\text { n (\%) }\end{array}$ & $\begin{array}{c}\text { Yes } \\
\text { n (\%) }\end{array}$ & $\begin{array}{l}\text { Total } \\
\text { n (\%) }\end{array}$ \\
\hline C-section & 225 (71.0) & $24(7.6)$ & $249(78.6)$ & $205(64.7)$ & $44(13.9)$ & $249(78.6)$ & $239(75.4)$ & $10(3.1)$ & $249(78.5)$ \\
\hline Forceps & $6(1.9)$ & $3(0.9)$ & $9(2.8)$ & $8(2.5)$ & $1(0.3)$ & $9(2.8)$ & $9(2.8)$ & - & $9(2.8)$ \\
\hline Vaginal & $57(18.0)$ & $2(0.6)$ & 59 (18.6) & $48(15.1)$ & $11(3.5)$ & 59 (18.6) & $55(17.4)$ & $4(1.3)$ & 59 (18.7) \\
\hline Total & $288(90.9)$ & $29(9.1)$ & $317(100)$ & 261 (82.3) & $56(17.7)$ & $317(100)$ & $303(95.6)$ & $14(4.4)$ & $317(100)$ \\
\hline
\end{tabular}

Table 5. Occurrence of complications among newborns with weight $\geq 2,500 \mathrm{~g}$

\begin{tabular}{|c|c|c|c|c|c|c|c|c|c|}
\hline \multirow{2}{*}{$\begin{array}{l}\text { Mode of } \\
\text { delivery }\end{array}$} & \multicolumn{3}{|c|}{$\begin{array}{c}\text { Anoxia } \\
\chi^{2}=49.12 ; p<0.001\end{array}$} & \multicolumn{3}{|c|}{$\begin{array}{c}\text { Respiratory distress } \\
\chi^{2}=12.85 ; \mathbf{p}=0.002\end{array}$} & \multicolumn{3}{|c|}{$\begin{array}{c}\text { Birth injury } \\
\chi^{2}=33.11 ; p<0.001\end{array}$} \\
\hline & $\begin{array}{c}\text { No } \\
\text { n (\%) }\end{array}$ & $\begin{array}{c}\text { Yes } \\
n(\%)\end{array}$ & $\begin{array}{l}\text { Total } \\
\text { n (\%) }\end{array}$ & $\begin{array}{c}\text { No } \\
\text { n (\%) }\end{array}$ & $\begin{array}{c}\text { Yes } \\
\text { n (\%) }\end{array}$ & $\begin{array}{l}\text { Total } \\
\text { n (\%) }\end{array}$ & $\begin{array}{c}\text { No } \\
\text { n (\%) }\end{array}$ & $\begin{array}{l}\text { Yes } \\
\text { n (\%) }\end{array}$ & $\begin{array}{l}\text { Total } \\
\text { n (\%) }\end{array}$ \\
\hline C-section & $4,740(66.2)$ & $216(3.0)$ & $4,956(69.2)$ & $4,800(67.0)$ & $156(2.2)$ & $4,956(69.2)$ & $4,672(65.2)$ & $284(4.0)$ & 4,956 (69.2) \\
\hline Forceps & 413 (5.8) & $55(0.8)$ & $468(6.6)$ & 449 (6.3) & $19(0.2)$ & 468 (6.5) & 335 (4.7) & 133 (1.8) & 468 (6.5) \\
\hline Vaginal & $1,651(23.0)$ & 88 (1.2) & $1,739(24.2)$ & $1,710(23.9)$ & $29(0.4)$ & $1,739(24.3)$ & $1,634(22.8)$ & $105(1.5)$ & $1,739(24.3)$ \\
\hline Total & $6,804(95.0)$ & $359(5.0)$ & $7,163(100)$ & $6,959(97.2)$ & 204 (2.8) & $7,163(100)$ & $6,641(92.7)$ & $522(7.3)$ & $7,163(100)$ \\
\hline
\end{tabular}




\section{Neonatal birth injury}

Neonatal birth injury occurred in $536 \mathrm{NB}$, corresponding to $7.1 \%$ of the total sample. In those born by C-section, it was present in 294 (3.9\%) neonates. In those born by forceps delivery, it occurred in 133 cases $(1.8 \%)$ and in those born by vaginal delivery, in $109(1.4 \%)$. The $\chi^{2}$ test revealed an association between this condition and the use of forceps, both compared to vaginal delivery $\left(\chi^{2}=188.82 ; \mathrm{p}<0.001\right)$, and with cesarean deliveries $\left(\chi^{2}=310.80 ; \mathrm{p}<0.001\right)$ (Table 1).

Neonatal birth injury occurred in 33 NB with less than 37 weeks of gestational age, corresponding to $8.3 \%$ of the children studied in this group: $19(4.8 \%)$ born by C-section, $8(2 \%)$ by forceps and $6(1.5 \%)$ by vaginal delivery. There was a statistically significant association between neonatal birth injury and the three modes of delivery $\left(\chi^{2}=18.29 ; p<0.001\right)$ (Table 2$)$, and the highest incidence of neonatal birth injury occurred when forceps was used.

Five hundred and three (7.1\%) NB with gestational age equal to or greater than 37 weeks had neonatal birth injury - in that, $275(3.9 \%)$ born by C-section, $125(1.8 \%)$ by forceps delivery and $103(1.4 \%)$ by vaginal delivery. There was a statistically significant association with the three types of delivery $\left(\chi^{2}=\right.$ 310.77; $\mathrm{p}<0.001$ ) (Table 3), the highest incidence in those born by forceps delivery.

Neonatal birth injury occurred in $14 \mathrm{NB}$ with weight between 1,500 and 2,499 g, 10 (3.1\%) born by $\mathrm{C}$-section and $4(1.3 \%)$ by vaginal delivery. In this weight group, there was no forceps delivery. The $\chi^{2}$ test was not statistically significant $\left(\chi^{2}=1.29\right.$; $\mathrm{p}=0.524)$ (Table 4).

A total of $522(7.3 \%)$ newborns with weight equal to or greater than 2,500 $\mathrm{g}$ had neonatal birth injury, out of which $284(4 \%)$ were born by C-section, $133(1.8 \%)$ by forceps and $105(1.5 \%)$ by vaginal delivery. There was a statistically significant association between neonatal birth injury and the three modes of delivery $\left(\chi^{2}=331.11\right.$; $\mathrm{p}<0.001$ ) (Table 5), with higher incidence among those born by forceps delivery.

\section{Calculated gestational age and estimated gestational age by the Capurro method}

There was no significant difference as for gestational age, estimated gestational age by the Capurro method and weight among NB with or without neonatal birth injury, delivered either vaginally or by $\mathrm{C}$-section.

Considering vaginal delivery ("normal" plus forceps), the Mann-Whitney test did not show association between anoxia and gestational age $(\mathrm{Z}=$ 1.001; $\mathrm{p}=0.313)$. There was significant association of the estimated gestational age by the Capurro method versus anoxia $(Z=1.37 ; p=0.170)$ as well as for weight versus anoxia $(Z=0.77 ; p=0.439)$.

For children born by C-section, there was a significant difference of anoxia in those with lower estimated gestational age by the Capurro method $(\mathrm{Z}=2.67 ; \mathrm{p}=0.007)$, as well as with lower weight $(\mathrm{Z}=2.65 ; \mathrm{p}=0.008)$.

Newborns with respiratory distress born by vaginal route had a significantly lower gestational age $(\mathrm{Z}=$ 7.319; $\mathrm{p}<0.004)$, lower estimated gestational age by the Capurro method $(\mathrm{Z}=7.63 ; \mathrm{p}<0.001)$ and lower weight $(Z=6.25 ; p<0.001)$. The results for neonates born by $\mathrm{C}$-section were significant as well: $\mathrm{Z}=12.19$; $\mathrm{p}$ $<0.001$ for gestational age; $Z=12.78 ; p<0.001$ for the estimated gestational age by the Capurro method and $\mathrm{Z}=8.46 ; \mathrm{p}<0.001$ for weight.

\section{DISCUSSION}

When analyzing the disorders in the total sample, that is, unrelated to gestational age or birth weight, it became evident that anoxia was significantly more frequent in children born by forceps delivery. The finding of the association of morbidity to the use of forceps is probably due to the indication for its use. For example, one of the maternal indications, prolonged expulsion phase, in which the forceps is used to finish the delivery if the fetus is showing signs of distress. According to the FEBRASGO manual( ${ }^{(7)}$, fetal indications are manifestations of acute fetal distress (situation in which the fetal heart rate does not return to normal 30 seconds after the end of contractions or fetal heart rate remains lower than 100 beats per minute (bpm) between contractions ${ }^{(8)}$, umbilical chord prolapse and premature fetus head protection, avoiding that a sudden decompression causes intracranial hematoma. "There is not an innocuous forceps"(7) is a well-known aphorism $^{(8)}$.

Among the newborns with anoxia, when the modes of delivery, weight, gestational age and estimated gestational age by the Capurro method were compared, only the neonates born by $\mathrm{C}$-section showed lower mean estimated gestational age by the Capurro method and lower birth weight, no difference was found for the other modes of delivery. This suggests that, probably, surgeries are performed and scheduled prior to the ideal timing for birth. Would the presence of fetal distress in this group of newborns explain anoxia at birth? It is worth questioning the difference mentioned, because the total number of newborns born by this route was 5,205 and the proportion of cesarean deliveries was $69.6 \%$. How many of these children were born before the appropriate timing, that is, iatrogenic prematurity, as exhaustively reported ${ }^{(9-13)}$. 
By analyzing respiratory distress in the entire sample, regardless of gestational age, there was a significant association between the syndrome and cesarean and/or forceps delivery. There was also a higher incidence of this disorder in cesarean and forceps deliveries in NB with more than 37 weeks of gestational age, or weight equal to or higher than $2,500 \mathrm{~g}$. Therefore, vaginal delivery was safer for these NB, which was explained in studies regarding the action of cathecolamines on fetal lungs during delivery ${ }^{(14-18)}$.

In the case of forceps delivery, the same considerations may be employed. It is important to notice that, in this sample, medium- and high-risk pregnancies are not included, and therefore it is not possible to attribute the increased presence of such disorder to this possibility. The C-section is used in situations of fetal distress or dystocia, among other indications, as quoted, yet all these indications do not justify the rate of such surgery in this hospital, nor the increased proportion of the disorder studied. This increase may be related to the surgery itself and/or with the timing of its performance: electively, when labor is not installed ${ }^{(10,16-23)}$. More than anoxia, the presence of respiratory distress may be correlated to the early performance of the surgery, before lung maturity is attained, characterizing once more iatrogenic prematurity ${ }^{(9-13)}$.

There was an increased incidence of neonatal birth injury in forceps deliveries and among children weighing 2,500 $\mathrm{g}$ or more and in newborns of all gestational ages. It is important to notice that neonatal birth injury is considered as any mark or sign found in the child after delivery even when it is only a scratch. Different grades of neonatal birth injury are usually reported in the charts, according to severity, but we choose not to analyze each grade separately. Hence, this condition may be considered inherent to the type of instrument used, since almost always the forceps leaves a mark in the child, no matter how small or transient ${ }^{(8)}$.

The present study looked at available data in nursery files, as spreadsheets, and, as such, it has some missing records, being the precise indication for $\mathrm{C}$-section the main one. Despite the high incidence of surgical delivery, because the obstetric chart was filled in by the obstetric nurse, the indication for surgery was not always properly recorded, whether because it was not directly informed by the obstetrician or for unknown reasons.

Another question that may raise doubts and/or discussion in the study refers to gestational age. Chart records show what is referred by the obstetrician according to the Näegele's rule. But the gestational age as seen on ultrasound was not found in all charts. For this reason, the analysis of gestational age records was also estimated by means of the Capurro method.

\section{CONCLUSIONS}

It may be concluded, from the presented data, that anoxia, neonatal birth injury and respiratory distress are associated with the mode of delivery; anoxia being significantly associated with forceps delivery when compared to vaginal and cesarean deliveries. Respiratory distress was more frequent in cesarean and in forceps deliveries and vaginal delivery is the safest for newborns with gestational age higher than 37 weeks and for those with weight greater than or equal to $2,500 \mathrm{~g}$. In newborns with gestational age lower than 37 weeks, neonatal birth injury was associated with type of delivery, the highest incidence for forceps delivery. In low birth weight newborns (between 1,500 and 2,499 g), there was an association between anoxia and the mode of delivery, with the highest incidence relating to forceps delivery. Considering only neonates born by $\mathrm{C}$-section, anoxia was associated with a lower estimated gestational age by the Capurro method and lower weight.

\section{REFERENCES}

1. World Health Organization. Appropriate technology for birth. Lancet. 1985;2(8452):436-7.

2. Agência Nacional de Saúde Suplementar. Proporção de parto cesáreo [Internet] [citado 2009 Maio 20]. Available from: http://www.ans.gov.br/ portal/upload/informacoesss/AS1fase.pdf.

3. Joffe M, Chapple J, Paterson C, Beard RW. What is the optimal caesarean section rate? An outcome based study of existing variation. J Epidemiol Community Health. 1994;48(4):406-11.

4. Duarte G, Figueiró Filho EA, Zola FE, Mauad Filho F. Operação cesariana: breve revisão. Femina. 2003;31(6):489-93

5. Hansen AK, Wisborg K, Uldbjerg N, Henriksen TB. Risk of respiratory morbidity in term infants delivered by elective caesarean section: cohort study. BMJ. 2008;336(7635):85-7.

6. Segre CA, Colletto GM, Bertagnon JR. Curvas de crescimento intrauterino de uma população de alto nível socioeconômico. J Pediatr (Rio J.). 2001;77(3):169-74.

7. Camano L. Manual de orientação FEBRASGO: Assistência ao parto e tocurgia. São Paulo: Ponto; 2002.

8. Rezende J. Obstetrícia. Rio de Janeiro: Guanabara Koogan; 1974.

9. Flaksman RJ, Vollman JH, Benfield DG. latrogenic prematurity due to elective termination of the uncomplicated pregnancy: a major perinatal health care problem. Am J Obstet Gynecol. 1978;132(8):885-8.

10. Miller JM Jr. Maternal and neonatal morbidity and mortality in cesarean section. Obstet Gynecol Clin North Am. 1988;15(14):629-38.

11. Faúndes A, Cecatti JG. A operação cesárea no Brasil: incidência, tendências, causas, conseqüências e propostas de ação. Cad Saúde Pública. $1991 ; 7(2): 150-73$.

12. Lippi UG, Blumer AS, Carvalho LA, Valverde VF, Segre CA. Prematuridade: alguns aspectos no Hospital Israelita Albert Einstein. Arq Cient. 1997;2(3):73-9. 
13. Maranhão AG, Joaquim MM, Siu C. Mortalidade perinatal e neonatal no Brasil. Tema. 1999;17:6-17.

14. Jones CM 3rd, Greiss FC Jr. The effect of labor on maternal and fetal circulating catecholamines. Am J Obstet Gynecol. 1982;144(2):149-53.

15. Puolakka J, Kauppila A, Tuimala R, Jouppila R, Vuori J. The effect of parturition on umbilical blood plasma levels of norepinephrine. Obstet Gynecol. 1983;61(1):19-21.

16. Brown MJ, Olver RE, Ramsden CA, Strang LB, Walters DV. Effects of adrenaline and of spontaneous labour on the secretion and absorption of lung liquid in the fetal lamb. J Physiol. 1983;344:137-52.

17. Brace RA. Fluid distribution in the fetus and neonate. In: Polin RA, Fox W, editors. Fetal and neonatal physiology. Philadelphia: Saunders; 1992. p. 1288-97.

18. Hägnevik K, Lagercrantz H, Sjöqvist BA. Establishment of functional residual capacity in infants delivered vaginally and by elective cesarean section. Early Hum Dev. 1991;27(1-2):103-10.
19. Bowers SK, MacDonald HM, Shapiro ED. Prevention of iatrogenic neonatal respiratory distress syndrome: elective repeat cesarean section and spontaneous labor. Am J Obstet Gynecol. 1982;143(2):186-9.

20. Heritage CK, Cunningham MD. Association of elective repeat cesarean delivery and persistent pulmonary hypertension of the newborn. Am J Obstet Gynecol. 1985; 152 (6 Pt 1):627-9.

21. Sandberg K, Sjöqvist BA, Hjalmarson 0, Olsson T. Effects of delivery by caesarean section on lung function in healthy newborn infants. Acta Paediatr Scand. 1986;75(3):470-6.

22. Braga LF. Cesariana - uso e abuso: Fatores da América do Sul e Brasil. Femina. 1988;16(12):1118-22.

23. Morrison JJ, Rennie JM, Milton PJ. Neonatal respiratory morbidity and mode of delivery at term: influence of timing of elective caesarean section. $\mathrm{Br} \mathrm{J}$ Obstet Gynaecol. 1995;102(2):101-6. 